BMJ Open

Diabetes

Research

\& Care

\title{
Islet inflammation is associated with pancreatic fatty infiltration and hyperglycemia in type 2 diabetes
}

\author{
Tomomi Horii, ${ }^{1}$ Yukari Fujita (D) , ${ }^{1,2}$ Chisaki Ishibashi, ${ }^{1}$ Kenji Fukui (D) , ${ }^{1}$ \\ Hidetoshi Eguchi, ${ }^{3}$ Junji Kozawa (D) , ${ }^{1,4}$ lichiro Shimomura ${ }^{1}$
}

To cite: Horii T, Fujita Y, Ishibashi C, et al. Islet inflammation is associated with pancreatic fatty infiltration and hyperglycemia in type 2 diabetes. BMJ Open Diab Res Care 2020;8:e001508. doi:10.1136/ bmjdrc-2020-001508

- Additional material is published online only. To view, please visit the journal online (http://dx.doi.org/10.1136/ bmjdrc-2020-001508).

Received 29 April 2020 Revised 25 June 2020 Accepted 10 July 2020

Check for updates

\section{(c) Author(s) (or their} employer(s)) 2020. Re-use permitted under CC BY-NC. No commercial re-use. See rights and permissions. Published by BMJ.

${ }^{1}$ Department of Metabolic Medicine, Graduate School of Medicine, Osaka University, Suita, Osaka, Japan ${ }^{2}$ Department of Community Medicine, Graduate School of Medicine, Osaka University, Suita, Osaka, Japan ${ }^{3}$ Department of Gastroenterological Surgery, Graduate School of Medicine, Osaka University, Suita, Osaka, Japan

${ }^{4}$ Department of Diabetes Care Medicine, Graduate School of Medicine, Osaka University, Suita, Osaka, Japan

Correspondence to Dr Junji Kozawa; kjunji@endmet.med.osaka-u. ac.jp

\section{ABSTRACT}

Introduction Chronic inflammation is observed in type 2 diabetes islets, and fat deposition in the pancreas affects insulin secretion and glucose tolerance. However, the relationship between this inflammation and pancreatic fat deposition has not been elucidated.

Research design and methods We examined pancreatic sections from 60 Japanese patients obtained by pancreatectomy. We evaluated pancreatic fat-cell area (\%) and CD68-positive $\left(\mathrm{CD}^{\circ} 8^{+}\right)$cells per islet histologically and examined the relationships between these histological findings and various clinical parameters.

Results The number of $\mathrm{CD} 8^{+}$cells per islet in the diabetes group was significantly higher than that in the normal glucose tolerance group $(p=0.026)$. Moreover, $\mathrm{CD} 8^{+}$cells per islet were significantly correlated with body mass index $(r=0.33, p=0.0080)$, fasting $C$-peptide immunoreactivity ( $r=0.46, p=0.0042)$, homeostasis model assessment insulin resistance $(r=0.38, p=0.016)$, C-peptide index ( $r=0.38, p=0.018)$, the area under the glucose concentration curve ( $\mathrm{AUC}_{\text {glucose }}$ ) at the 75 $g$ oral glucose tolerance test $(r=0.49, p=0.0065)$ and fat-cell area $(r=0.51, p<0.0001)$. In multiple regression analyses, fat-cell area $(\beta=0.600, p=0.0027)$ and $A U C_{\text {glucose }}$ $(\beta=0.453, p=0.0042)$ were the independent and significant determinants of $\mathrm{CD}^{+} 8^{+}$cells per islet.

Conclusion The inflammation of islets is associated with pancreatic fatty infiltration and hyperglycemia, which may further aggravate glucose tolerance.

\section{INTRODUCTION}

Type 2 diabetes is characterized by insulin resistance and impaired insulin-secreting capacity. Chronic inflammation in various organs is observed in patients with type 2 diabetes $^{12}$ and is associated with insulin resistance. ${ }^{3}$ Inflammation in adipose tissue and the liver has been well studied, ${ }^{45}$ and this inflammation is closely associated with obesity, including metabolic syndrome. ${ }^{45}$ It has recently been reported that increased pancreatic islet-associated immune cells were also observed in patients with human type 2 diabetes, high-fat diet-fed C57BL/6J mice, GK rats and $\mathrm{db} / \mathrm{db}$ mice, ${ }^{6}$ where macrophages were the most frequent immune cells. ${ }^{7} \beta$-cell

\section{Significance of this study}

What is already known about this subject?

- Pancreatic islet inflammation is observed in patients with human type 2 diabetes, where macrophages are the most frequent immune cells.

- Fat deposition in the pancreas could affect insulin secretion and glucose tolerance.

What are the new findings?

- The degree of islet inflammation was higher in patients with type 2 diabetes than that in subjects with normal glucose tolerance.

- Islet inflammation was closely associated with pancreatic fat deposition and hyperglycemia.

How might these results change the focus of research or clinical practice?

- Future study should focus on the relationship between islet inflammation and longitudinal change of insulin-secreting capacity in type 2 diabetes.

- Diabetes therapy focusing on reducing pancreatic fat deposition might have the possibility that islet inflammation could ameliorate, resulting in more preserved $\beta$-cell function.

dysfunction with worsening glucose tolerance might be partly derived from this type of inflammation. ${ }^{8}$ However, the etiology and pathophysiology of this islet inflammation have not been elucidated.

Pancreatic fatty infiltration is one of the ectopic fat depositions, as are visceral fat accumulation and fatty liver. These ectopic fat depositions may be derived from lipid oversupply and may be associated with the elevation of intracellular lipid metabolites and/or fatty infiltration, which is adipocyte infiltration. ${ }^{9}$ Fatty liver, which is lipid deposition in hepatocytes, induces inflammation and progression to non-alcoholic steatohepatitis $^{5}$; thus, ectopic fat deposition might be one of the causes of organ inflammation, leading to organ failure. We demonstrated that pancreatic fat deposition evaluated by 
CT scans was strongly and positively associated with the longitudinal decrease in endogenous insulin-secreting capacity, $^{10}$ and we also showed that histological pancreatic fatty infiltration had a strong correlation with glucose intolerance within 1 year of pancreatectomy in preoperative patients without diabetes. ${ }^{11}$ In Zucker diabetic fatty rats, triglyceride accumulation in the exocrine pancreas precedes the onset of overt diabetes. $^{12}$

Thus, the association of chronic inflammation with type 2 diabetes and the association of pancreatic fat deposition with type 2 diabetes have been studied, but it is unclear whether this islet inflammation is relevant to pancreatic fat deposition. We aimed to clarify the relationship between islet inflammation, evaluated by macrophage infiltration, and pancreatic fatty infiltration in patients with various degrees of glucose intolerance by immunohistochemical analyses.

\section{RESEARCH DESIGN AND METHODS}

Patients

We enrolled 60 Japanese patients who had undergone pancreatic resection between 2008 and 2013 and between 2018 and 2019 at the Department of Gastroenterological Surgery, Osaka University Hospital, and had agreed to participate in this study. Patients with renal failure (estimated glomerular filtration rate $<30 \mathrm{~mL} / \mathrm{min} / 1.73 \mathrm{~m}^{2}$ ) and patients with pancreatic endocrine tumors were excluded from this study. Patients underwent a $75 \mathrm{~g}$ oral glucose tolerance test (OGTT) at 1-60 days before pancreatic resection, and the results of the test were used to classify the patients into three groups: normal glucose tolerance (NGT), impaired glucose tolerance (IGT), and diabetes mellitus (DM). One patient was diagnosed with new DM without the $75 \mathrm{~g}$ OGTT based on his medical history. The DM group included patients undergoing long-term medical intervention.

\section{Laboratory tests}

We evaluated glycated hemoglobin (HbAlc) (\%, mmol/ $\mathrm{mol})$, fasting plasma glucose (FPG) (mmol/L), fasting C-peptide immunoreactivity (F-CPR) (nmol/L), the C-peptide index (CPI) ( $\mathrm{nmol} / \mathrm{mmol})$, the insulinogenic index (II) (pmol/mmol), homeostasis model assessment insulin resistance (HOMA-IR), the area under the glucose concentration curve $\left(\mathrm{AUC}_{\text {glucose }}\right)$ at $75 \mathrm{~g}$ OGTT $(\mathrm{min} \cdot \mathrm{mmol} / \mathrm{L}), \mathrm{C}$ reactive protein $(\mathrm{CRP})(\mathrm{mg} / \mathrm{L})$, and serum total amylase (IU/L).

\section{Pancreatic tissue processing}

We obtained normal pancreatic tissue samples from patients who had undergone pancreatic resection. The tissues were isolated from near the resected margins after intraoperative consultation, fixed immediately in formaldehyde, and embedded in paraffin, and 5 $\mu \mathrm{m}$ sections were cut for subsequent analysis. Paraffinembedded tissue was stained with $\mathrm{H} \& \mathrm{E}$ and confirmed to contain no cancerous elements. Sections with $>30 \%$ fibrous area estimated by Azan staining were excluded from this study.

\section{Immunohistochemistry}

Primary and secondary antibodies are listed in the online supplementary table. To evaluate intraislet and peripheral islet macrophages, we performed double immunofluorescent staining for insulin and CD68, which is a marker of macrophages. The sections were incubated with rabbit anti-CD68 antibody and biotinylated secondary antibody, followed by Alexa Fluor 488-conjugated streptavidin. Sections were costained with guinea pig anti-insulin antibody, followed by rhodamine-conjugated antibody. We counted the number of CD68-positive $\left(\mathrm{CD}^{+} 8^{+}\right)$cells per islet, which was defined as $\mathrm{CD} 68^{+}$cells around the periphery and/ or within islets of more than $100 \mu \mathrm{m}$ in diameter and expressed as the number per unit of islet. We observed $89.5 \pm 65.8$ islets per section.

\section{Assessment of pancreatic fatty infiltration}

Pancreatic fatty infiltration was evaluated as the fat-cell area in the pancreas histologically. The ratio of the sum of the interlobular and intralobular fat-cell area to the entire pancreatic section was defined as 'fat-cell area' (\%). ${ }^{13}$ A mean section area of $101.4 \pm 35.5 \mathrm{~mm}^{2}$ was examined for each section. The fat-cell area was quantified using the Win ROOF software program (Mitani Corporation, Fukui, Japan). ${ }^{11}$

\section{Statistical analysis}

Normally distributed data are presented as the means $\pm \mathrm{SD}$, and non-normally distributed data are presented as the medians and IQRs. Normally distributed data were compared by one-way analysis of variance followed by a post hoc Tukey-Kramer analysis. Non-normally distributed data were compared using the Kruskal-Wallis test followed by a post hoc SteelDwass analysis. Multivariable regression analyses were used to assess independent determinants. All statistical analyses were performed with JMP Pro V.14 software (Statistical Analysis System, Cary, North Carolina, USA). Significance was set at $\mathrm{p}<0.05$.

\section{RESULTS}

\section{Clinical characteristics and laboratory data}

Table 1 shows a comparison of the clinical characteristics among the groups. Patients were classified as NGT $(n=21)$, IGT $(n=15)$, or DM $(n=24)$. Primary diseases were mainly cystic lesions of the pancreas $(n=25)$ and pancreatic cancer $(n=19)$. The surgical procedures were pancreatoduodenectomy $(n=35)$ and distal pancreatectomy $(n=25)$. There were no differences among the groups with respect to age, BMI, F-CPR, CPI, HOMA-IR, CRP or amylase. HbA1c levels were significantly higher in the IGT group than in the NGT group 
Table 1 Clinical characteristic of subjects

\begin{tabular}{|c|c|c|c|c|}
\hline & Total & NGT & IGT & DM \\
\hline $\mathrm{n}$ & 60 & 21 & 15 & 24 \\
\hline Male/female & $33 / 28$ & $10 / 11$ & $7 / 8$ & $16 / 8$ \\
\hline Age (years) & $60.1 \pm 15.1$ & $52.4 \pm 16.7$ & $54.8 \pm 14.4$ & $69.9 \pm 6.9^{\star \star} \dagger$ \\
\hline BMI $\left(\mathrm{kg} / \mathrm{m}^{2}\right)$ & $21.8 \pm 3.3$ & $21.1 \pm 2.6$ & $22.0 \pm 3.9$ & $22.4 \pm 3.5$ \\
\hline $\begin{array}{l}\mathrm{HbA} 1 \mathrm{c} \\
(\%, \mathrm{mmol} / \mathrm{mol})\end{array}$ & $5.9 \pm 1.0,41 \pm 10$ & $5.2 \pm 0.5,33 \pm 5$ & $5.8 \pm 0.4,{ }^{\star \star} 39 \pm 4$ & $6.7 \pm 0.9,{ }^{\star *} \dagger 49 \pm 10$ \\
\hline $\mathrm{FPG}(\mathrm{mmol} / \mathrm{L})$ & $5.6 \pm 1.1(n=56)$ & $5.2 \pm 0.5(n=20)$ & $5.2 \pm 0.3(n=14)$ & $6.3 \pm 1.3^{\star \star} \ddagger(n=22)$ \\
\hline F-CPR (nmol/L) & $0.4 \pm 0.2(n=36)$ & $0.52 \pm 0.2(n=14)$ & $0.59 \pm 0.1(n=7)$ & $0.40 \pm 0.2(n=15)$ \\
\hline $\mathrm{CPI}(\mathrm{nmol} / \mathrm{mmol})$ & $0.09 \pm 0.04(n=36)$ & $0.10 \pm 0.02(n=14)$ & $0.1 \pm 0.02(n=7)$ & $0.07 \pm 0.04^{*}(n=15)$ \\
\hline II (pmol/mmol) & $84.1 \pm 60.9(n=28)$ & $103.2 \pm 68.4(n=13)$ & $111.7 \pm 32.9(n=7)$ & $29.1 \pm 21.7^{*} \dagger(n=8)$ \\
\hline HOMA-IR & $1.5 \pm 0.8(n=38)$ & $1.4 \pm 0.7(n=16)$ & $1.7 \pm 0.9(n=10)$ & $1.4 \pm 0.8(n=12)$ \\
\hline $\begin{array}{l}\text { AUC }_{\text {glucose }} \\
(\mathrm{min} \cdot \mathrm{mmol} / \mathrm{L})\end{array}$ & $17.4 \pm 4.3(n=29)$ & $15.0 \pm 3.0(n=14)$ & $16.1 \pm 2.3(n=7)$ & $22.9 \pm 2.6^{\star *} \dagger(n=8)$ \\
\hline CRP (mg/L) & $0.8 \pm 2.4$ & $0.4 \pm 0.4$ & $0.4 \pm 0.9$ & $1.5 \pm 3.6$ \\
\hline Total amylase, IU/L & $99.1 \pm 73.2(n=59)$ & $96.4 \pm 61.2(n=21)$ & $89.7 \pm 107.6(n=15)$ & $107.6 \pm 94.9(n=23)$ \\
\hline Fat-cell area, \% & $3.4 \pm 8.1$ & $2.5 \pm 3.8$ & $6.6 \pm 15.2$ & $2.2 \pm 2.6$ \\
\hline $\begin{array}{l}\text { Medication for } \\
\text { diabetes }\end{array}$ & & - & - & $\begin{array}{l}\text { None: } 11 \\
\text { SU: } 4, \alpha G I: 2, \text { DPP-4I: } 3 \text {, } \\
\text { Metformin: 3, SGLT-2I: } 1 \text {, } \\
\text { Insulin: } 6\end{array}$ \\
\hline Underlying disease & $\begin{array}{l}\text { Pancreatic cancer: } 19 \\
\text { IPMN: } 18 \\
\text { Serous cystic adenoma: } \\
3 \\
\text { Mucinous cystic } \\
\text { adenoma: } 2 \\
\text { Solid pseudo-papillary } \\
\text { neoplasm: } 6 \\
\text { Bile duct cancer: } 2 \\
\text { Carcinoma of the papilla } \\
\text { of Vater: } 3 \\
\text { pNET: } 3 \\
\text { Simple cyst: } 1 \\
\text { Pseudocyst of pancreas: } \\
1 \\
\text { Adenocarcinoma of the } \\
\text { duodenum: } 1 \\
\text { Pancreatic metastasis } \\
\text { from renal cell } \\
\text { carcinoma: } 1\end{array}$ & $\begin{array}{l}\text { Pancreatic cancer: } 4 \\
\text { IPMN: } 5 \\
\text { Serous cystic adenoma: } \\
1 \\
\text { Solid pseudo-papillary } \\
\text { neoplasm: } 5 \\
\text { Bile duct cancer: } 1 \\
\text { Carcinoma of the papilla } \\
\text { of Vater: } 2 \\
\text { pNET: } 1 \\
\text { Simple cyst: } 1 \\
\text { Pseudocyst of pancreas: } \\
1\end{array}$ & $\begin{array}{l}\text { Pancreatic cancer: } 6 \\
\text { IPMN: } 3 \\
\text { Serous cystic adenoma: } \\
1 \\
\text { Mucinous cystic } \\
\text { adenoma: } 2 \\
\text { Solid pseudo-papillary } \\
\text { neoplasm: } 1 \\
\text { pNET: } 1 \\
\text { Adenocarcinoma of the } \\
\text { duodenum: } 1\end{array}$ & $\begin{array}{l}\text { Pancreatic cancer: } 9 \\
\text { IPMN: } 10 \\
\text { Serous cystic adenoma: } 1 \\
\text { Bile duct cancer: } 1 \\
\text { Carcinoma of the papilla } \\
\text { of Vater: } 1 \\
\text { pNET: } 1 \\
\text { Pancreatic metastasis } \\
\text { from renal cell carcinoma: } \\
1\end{array}$ \\
\hline
\end{tabular}

Values are mean \pm SD. Statistical analyses were performed by one-way analysis of variance followed by post hoc Tukey-Kramer analysis.

$\mathrm{CPI}$ is the fasting C-peptide/FPG.

II is $\triangle I R I[I R I 30 \mathrm{~min}-\mathrm{IRI} 0 \mathrm{~min}] / \triangle \mathrm{PG}[\mathrm{PG} 30 \mathrm{~min}-\mathrm{PG} 0 \mathrm{~min}]$.

${ }^{*} \mathrm{P}<0.05$ versus $\mathrm{NGT},{ }^{\star \star} \mathrm{P}<0.01$ versus $N G T, \dagger P<0.01$ versus IGT, $\neq \mathrm{P}<0.05$ versus IGT.

$\mathrm{AUC}_{\text {glucose, }}$, area under the glucose concentration curve using the trapezoid method; BMI, body mass index; CPI, C-peptide index; CRP, C reactive protein; DM, diabetes mellitus; DPP-4I, dipeptidyl peptidase-4 inhibitor; F-CPR, fasting C-peptide immunoreactivity; FPG, fasting plasma glucose; $\alpha \mathrm{Gl}, \alpha$-glucosidase inhibitor; HbA1c, glycated hemoglobin; HOMA-IR, homeostasis model assessment of insulin resistance; IGT, impaired glucose tolerance; IPMN, intraductal papillary mucinous neoplasm; NGT, normal glucose tolerance; pNET, pancreatic neuroendocrine tumor; SGLT-2I, sodium-glucose co-transporter 2 inhibitor; SU, sulfonylurea.

$(\mathrm{p}<0.01)$ and higher in the DM group than in the NGT $(\mathrm{p}<0.01)$ and IGT $(\mathrm{p}<0.01)$ groups. The FPG level in the DM group was significantly higher than those in the NGT $(p<0.01)$ and IGT $(p<0.05)$ groups. The II was lower in the DM group than in the NGT $(p<0.05)$ and
IGT $(\mathrm{p}<0.01)$ groups. $\mathrm{AUC}_{\text {glucose }}$ was significantly higher in the DM group than in the NGT $(\mathrm{p}<0.01)$ and IGT $(p<0.01)$ groups. In the DM group, 11 patients did not receive any medications for diabetes, and 13 patients received oral antidiabetic agents and/or insulin. 


\section{Pancreatic fat-cell area}

Representative views of pancreatic fat cells stained by $\mathrm{H} \& \mathrm{E}$ are shown in figure $1 \mathrm{~A}$. There were no significant differences in fat-cell area among the three groups (NGT: $2.5 \pm 3.8 \%$ vs IGT: $6.6 \pm 15.2 \%$ vs DM: $2.2 \% \pm 2.6 \%, \mathrm{p}=0.209)$ (figure 1B). Fat-cell area had a significant correlation with HOMA-IR ( $r=0.54, p=0.0004)$, BMI $(r=0.47, p=0.0002)$, F-CPR $(r=0.40, p=0.015)$ and CPI $(r=0.34, p=0.040)$ but not with age $(\mathrm{r}=-0.12, \mathrm{p}=0.330)$, HbAlc $(\mathrm{r}=0.04$, $\mathrm{p}=0.740)$, FPG $(\mathrm{r}=0.05, \mathrm{p}=0.689)$, II $(\mathrm{r}=0.09, \mathrm{p}=0.640)$, $\mathrm{AUC}_{\text {glucose }} \cdot(\mathrm{r}=0.11, \mathrm{p}=0.558), \mathrm{CRP}(\mathrm{r}=-0.03, \mathrm{p}=0.819)$ or amylase $(r=-0.09, p=0.473)$ (figure $1 \mathrm{C}$ ).

\section{Intraislet and peripheral islet macrophages}

Figure 2 shows a comparison of the number of $\mathrm{CD} 68^{+}$ cells per islet among the groups and the correlation coefficient between the number of $\mathrm{CD}^{+} 8^{+}$cells per islet and clinical parameters. A representative image showing a CD68-immunopositive cell around the periphery of an islet from a patient with DM is shown in figure 2A. The median $\mathrm{CD}^{+} 8^{+}$cells per islet were 0 (IQR, 0.04), 0.017 (IQR, 0.07), and 0.05 (IQR, 0.12) in the NGT, IGT, and $\mathrm{DM}$ groups, respectively. The number of $\mathrm{CD}^{+} 8^{+}$cells per islet in DM was significantly higher than that in NGT ( $p=0.026$ ) (figure 2B). $\mathrm{CD}^{+}$cells per islet were associated with BMI $(\mathrm{r}=0.33, \mathrm{p}=0.0080)$, F-CPR $(\mathrm{r}=0.46$, $\mathrm{p}=0.0042)$, HOMA-IR $(\mathrm{r}=0.38, \mathrm{p}=0.016)$, CPI $(\mathrm{r}=0.38$, $\mathrm{p}=0.018)$, and $\mathrm{AUC}_{\text {glucose }}(\mathrm{r}=0.49, \mathrm{p}=0.0065)$ but not with age $(\mathrm{r}=0.19, \mathrm{p}=0.140)$, HbA1c $(\mathrm{r}=0.22, \mathrm{p}=0.080)$, FPG $(\mathrm{r}=0.15, \mathrm{p}=0.253)$, II $(\mathrm{r}=-0.19, \mathrm{p}=0.316)$, CRP $(\mathrm{r}=0.18$, $\mathrm{p}=0.160)$ or amylase $(\mathrm{r}=0.01, \mathrm{p}=0.932)$. In addition, we observed a significant correlation between the number of $\mathrm{CD}^{+} 8^{+}$cells per islet and fat-cell area $(\mathrm{r}=0.51, \mathrm{p}<0.0001)$ (figure 2C). In multiple regression analyses, both fatcell area $(\beta=0.600, p=0.0027)$ and $\mathrm{AUC}_{\text {glucose }}(\beta=0.453$, $\mathrm{p}=0.0042)$ were independent and significant determinants (table 2).

\section{CONCLUSIONS}

We observed that islet-associated macrophage infiltration in type 2 diabetes increased compared with NGT, and this is the first study showing significant correlations between pancreatic fat deposition as well as hyperglycemia and islet inflammation.

We observed a significant correlation between the number of islet-associated macrophages and fat-cell area. In a previous report, a significantly higher number of macrophages were found in the islets located in proximity to adipocytes than in other islets. ${ }^{14}$ These results might indicate that macrophages are recruited to the islets by pancreatic fatty infiltration. One of the key substances that recruits macrophages to islets with pancreatic fatty infiltration may be a saturated fatty acid, palmitate. $\beta$ cells respond to palmitate via the Toll-like receptor pathway and produce chemokines, including interleukin (IL)-8, IL-6 and monocyte chemotactic protein-1 (MCP1) ${ }^{14}$ that recruit M1-type proinflammatory monocytes/ macrophages to the islets. ${ }^{15}$ The pancreatic fat-cell area was positively correlated with BMI and HOMA-IR in this study, suggesting that pancreatic fat deposition might be exacerbated by obesity. This is consistent with some previous studies that report a significant correlation between pancreatic fat and BMI. ${ }^{91016}$ In another report, fatty pancreas diagnosed by sonographic findings was also associated with visceral fat area and HOMA-IR in subjects without diabetes, ${ }^{17}$ which indicates that excess pancreatic fat deposition could be one of the components of metabolic syndrome. In our study, there was no significant difference in fat-cell area among the three stages of glucose tolerance groups, which might be derived from no significant difference in BMI among the groups.

This study has shown that islet inflammation in type 2 diabetes may be exacerbated not only in relation to excess pancreatic fat deposition but also hyperglycemia. Although there was no significant difference in pancreatic fat-cell area among the three glucose tolerance groups, the number of islet-associated macrophages was significantly increased in patients with diabetes compared with patients without diabetes, suggesting that the islet inflammation shown in our study could be greatly attributed to a hyperglycemic state. The mechanism that explains why macrophages are recruited to the islets by hyperglycemia may be as follows. Hyperglycemia increases IL-1 $\beta$ mRNA levels in $\beta$ cells. ${ }^{18}$ Because $\beta$ cells express IL-1 receptor type $1, \beta$ cells secrete chemokines in response to IL-1 $\beta$ in an autocrine or paracrine manner, which leads to the recruitment of macrophages and a vicious cycle of inflammation. ${ }^{8}$ On the other hand, a previous report showed that there was no significant difference in the number of islet-associated macrophages between patients with type 2 diabetes and those without. ${ }^{19}$ In that report, both groups of patients were obese, and obesity induced inflammation, as described previously. ${ }^{45}$ It is speculated that the impact of obesity on islet inflammation might obscure the impact of hyperglycemia in that study. Since most patients were not obese at all glucose tolerance stages in our study, the impact of hyperglycemia might become apparent.

CRP level, which is one of the sensitive physiological markers of systemic inflammation, did not show a significant difference among the three groups. CRP level, which is generally associated with $\mathrm{BMI},{ }^{20}$ was positively correlated with BMI $(\mathrm{r}=0.29, \mathrm{p}=0.022)$ but not with the glycemic parameters or fat-cell area (online supplementary figure 1). These results might suggest that obesity causes both whole-body inflammation and islet inflammation, while hyperglycemia also affects islet inflammation rather than whole-body inflammation. We also evaluated serum total amylase level as one of the possible local inflammation parameters of pancreas. The amylase level did not show a significant difference among the three groups, and this level was not correlated with any clinical parameters or fat-cell area (online supplementary figure 2). In addition, the amylase level was not correlated with the number of islet-associated macrophages (data not 
A
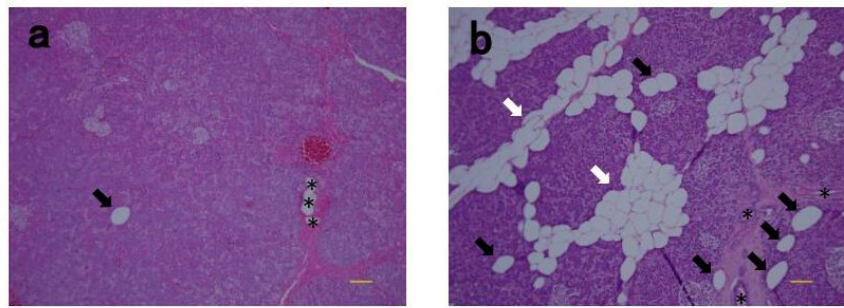

B

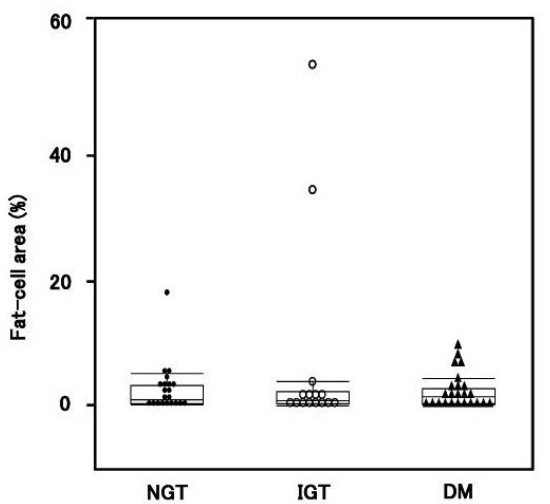

C


Figure 1 Intrapancreatic fat-cell area. (A) Representative views of H\&E-stained sections: (a) patient with DM aged 60 years; fat-cell area, 0.06\%; BMI, $20.9 \mathrm{~kg} / \mathrm{m}^{2}$; (b) patient with IGT aged 20 years; fat-cell area, $52.7 \%$; BMI, $34.3 \mathrm{~kg} / \mathrm{m}^{2}$. Fat-cell area was quantified as the scattered and spread interlobular (white arrows) and intralobular (black arrows) fat-cell area, distinguished from lymph ducts or vessels (asterisk) by the absence of surrounding connective tissue and endothelial cells. Scale bars: 100 $\mu \mathrm{m}$. (B) Comparisons of the fat-cell area among the NGT, IGT, and DM groups. (C) Correlation coefficient between fat-cell area and clinical parameters of age, BMI, HbA1c, FPG, CPR, C-peptide index, insulinogenic index, HOMA-IR, AUC glucose , CRP and


under the glucose concentration curve; BMI, body mass index; CPR, C-peptide immunoreactivity; CRP, C reactive protein; DM, diabetes mellitus; FPG, fasting plasma glucose; HbA1c, glycated hemoglobin; HOMA-IR, homeostasis model assessment insulin resistance; IGT, impaired glucose tolerance; NGT, normal glucose tolerance. 
A

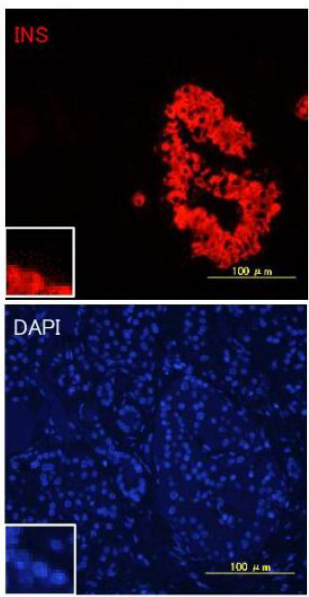

B

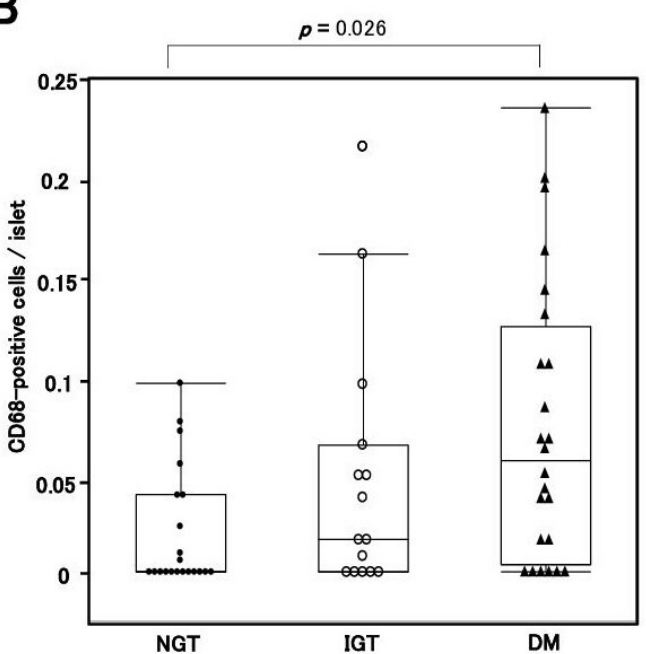

C
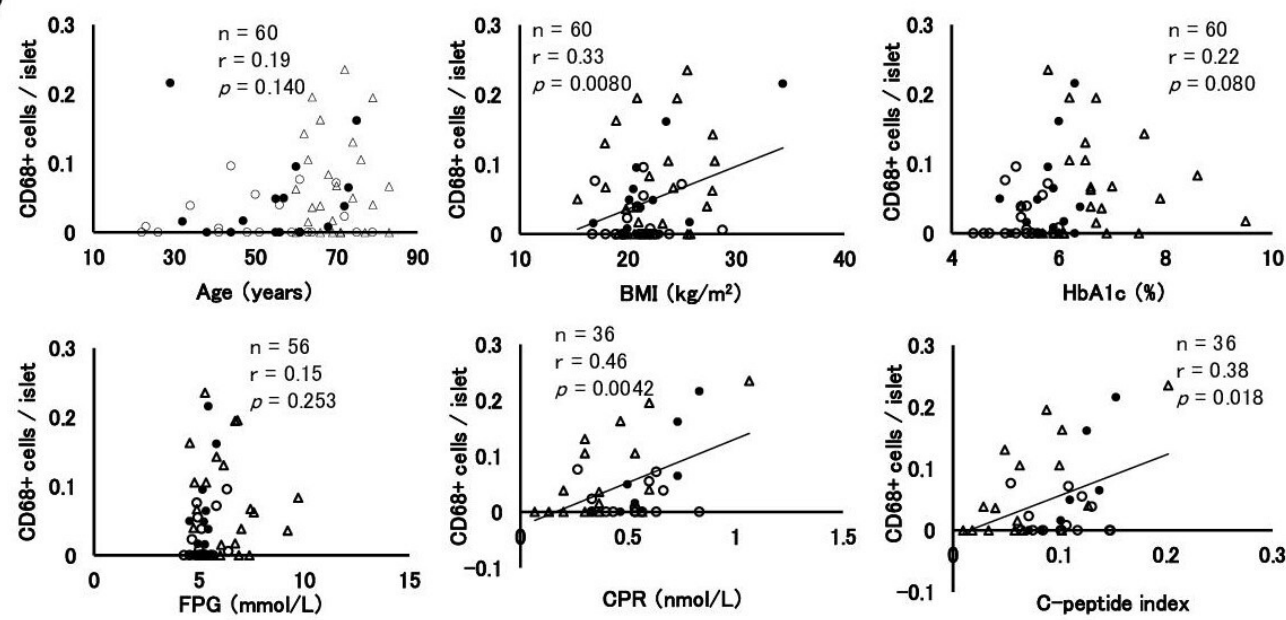

CPR (nmol/L)
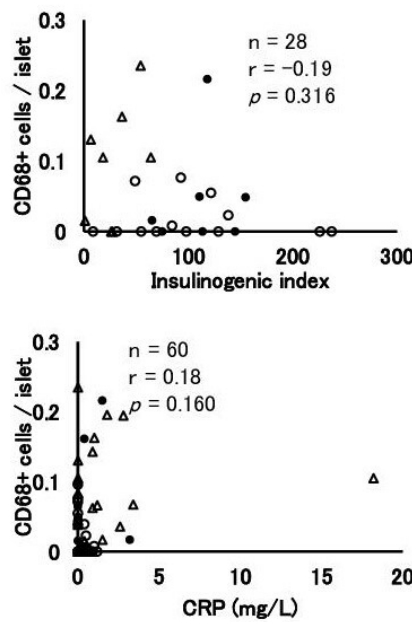
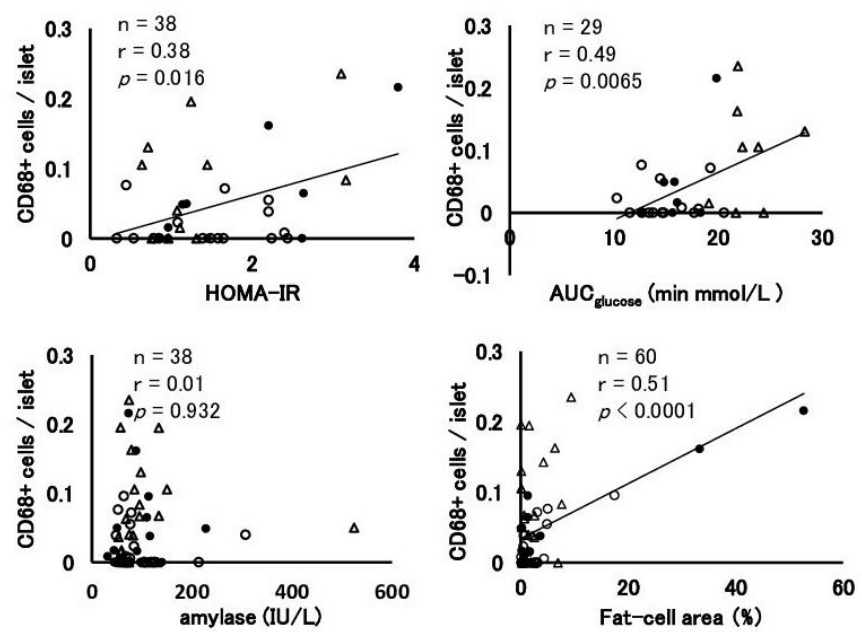



Figure 2 Intraislet and peripheral islet macrophages. (A) Immunofluorescence staining for insulin (INS) (red), CD68 (green) and 4',6-diamidino-2-phenylindole (DAPI) (blue) in a patient with NGT. (B) Comparisons of the CD68 ${ }^{+}$cells per islet among the NGT, IGT, and DM groups. (C) Correlation coefficient between $\mathrm{CD}^{+} 8^{+}$cells per islet and parameters of age, BMI, HbA1c, FPG, CPR, C-peptide index, insulinogenic index, HOMA-IR, AUC ${ }_{\text {glucose }}$, CRP, amylase and fat-cell area. Closed circles (O), the NGT group; open circles (O), the IGT group; closed triangles (A), the DM group. AUC $\mathrm{Clucose}_{\text {, }}$ area under the glucose concentration curve; BMI, body mass index; CPR, C-peptide immunoreactivity; CRP, C reactive protein; DM, diabetes mellitus; FPG, fasting plasma glucose; HbA1c, glycated hemoglobin; HOMA-IR, homeostasis model assessment insulin resistance; IGT, impaired glucose tolerance; NGT, normal glucose tolerance. 
Table 2 Multiple regression analyses for determinants of the number of islet macrophage

\begin{tabular}{|c|c|c|c|}
\hline & Coefficient & $\begin{array}{l}\text { Standardized } \\
\text { coefficient }\end{array}$ & $P$ value \\
\hline \multicolumn{4}{|l|}{ Model 1, n=38 } \\
\hline $\begin{array}{l}\text { Fat-cell area } \\
(\%)\end{array}$ & 0.0031 & 0.451 & 0.022 \\
\hline $\mathrm{BMI}\left(\mathrm{kg} / \mathrm{m}^{2}\right)$ & 0.0025 & 0.122 & 0.487 \\
\hline HOMA-IR & 0.0071 & 0.087 & 0.607 \\
\hline \multicolumn{4}{|l|}{ Model 2, n=29 } \\
\hline $\begin{array}{l}\text { Fat-cell area } \\
(\%)\end{array}$ & 0.0041 & 0.600 & 0.0027 \\
\hline $\mathrm{BMI}\left(\mathrm{kg} / \mathrm{m}^{2}\right)$ & -0.0016 & -0.090 & 0.634 \\
\hline $\begin{array}{l}\text { AUC } \\
\text { (min'mmocose } \\
\text { mil/L) }\end{array}$ & 0.0069 & 0.453 & 0.0042 \\
\hline \multicolumn{4}{|l|}{ Model 3, n=36 } \\
\hline $\begin{array}{l}\text { Fat-cell area } \\
(\%)\end{array}$ & 0.0028 & 0.425 & 0.021 \\
\hline $\mathrm{BMI}\left(\mathrm{kg} / \mathrm{m}^{2}\right)$ & 0.0013 & 0.071 & 0.678 \\
\hline $\begin{array}{l}\text { F-CPR } \\
\text { (nmol/L) }\end{array}$ & 0.089 & 0.269 & 0.084 \\
\hline \multicolumn{4}{|l|}{ Model 4, n=28 } \\
\hline $\begin{array}{l}\text { Fat-cell area } \\
\text { (\%) }\end{array}$ & 0.0027 & 0.397 & 0.036 \\
\hline HOMA-IR & 0.019 & 0.226 & 0.216 \\
\hline $\begin{array}{l}\text { AUC } \\
\text { (min'mmose } \\
\text { mol/L) }\end{array}$ & 0.0067 & 0.442 & 0.0029 \\
\hline \multicolumn{4}{|l|}{ Model $5, n=32$} \\
\hline $\begin{array}{l}\text { Fat-cell area } \\
(\%)\end{array}$ & 0.0036 & 0.545 & 0.0060 \\
\hline HOMA-IR & -0.024 & -0.274 & 0.373 \\
\hline $\begin{array}{l}\text { F-CPR } \\
\text { (nmol/L) }\end{array}$ & 0.171 & 0.439 & 0.118 \\
\hline \multicolumn{4}{|l|}{ Model 6, $n=24$} \\
\hline $\begin{array}{l}\text { Fat-cell area } \\
(\%)\end{array}$ & 0.0031 & 0.467 & 0.0093 \\
\hline $\begin{array}{l}\mathrm{AUC} \mathrm{g}_{\text {gluosese }} \\
\text { (min.mmol/L) }\end{array}$ & 0.0064 & 0.421 & 0.0089 \\
\hline $\begin{array}{l}\text { F-CPR } \\
\text { (nmol/L) }\end{array}$ & 0.075 & 0.204 & 0.223 \\
\hline
\end{tabular}

$\mathrm{AUC}_{\text {glucose}}$, area under the glucose concentration curve; BMI, body mass index; F-CPR, fasting C-peptide immunoreactivity; HOMA$\mathrm{IR}$, homeostasis model assessment insulin resistance.

shown). These results might suggest that macrophages recruited by pancreatic fatty infiltration and hyperglycemia might injure $\beta$ cells rather than the entire pancreas.

A previous study reported that islet inflammation derived from lipotoxity could deteriorate $\beta$-cell function in experimental animal models. ${ }^{15} \mathrm{~A}$ direct negative association between islet inflammation and insulin-secreting capacity was not observed in our study, but referring to this report, we found that the increased islet inflammation observed in patients with type 2 diabetes might promote the worsening of glucose intolerance.

One patient with DM had received sodium-glucose co-transporter-2 (SGLT-2) inhibitor before pancreatic resection. We consider that SGLT-2 inhibitors might ameliorate pancreatic steatosis, where such effect is observed in visceral adipose tissue,${ }^{21}$ and affect the results. Thus, we investigated again after excluding the patient; however, the results did not change (data not shown). The effect of SGLT-2 inhibitors on fat deposition and islet inflammation would be further investigated in the future.

There is a limitation in our study. It is difficult to exclude the impact of the primary diseases on histological findings or clinical backgrounds because some individuals in this study had malignant diseases of the pancreas, hepatobiliary system and duodenum. However, there were no significant differences in islet-associated macrophage and pancreatic fat-cell area between patients with malignant diseases and those without (data not shown).

In conclusion, islet inflammation occurs in association with pancreatic fatty infiltration and glucose intolerance and may contribute to further worsening of glucose intolerance.

Acknowledgements We thank Ms. Misako Kobayashi for excellent technical assistance.

Contributors TH analyzed the data and wrote the manuscript. YF and KF contributed to the discussion. HE examined the patients and obtained pancreatic tissue samples. YF and JK analyzed the data and reviewed/edited the manuscript. IS contributed to the discussion and reviewed/edited the manuscript. TH is the guarantor of this work and, as such, had full access to all the data in the study and takes responsibility for the integrity of the data and the accuracy of data analysis.

Funding This study was supported in part by G-7 Scholarship Foundation.

Competing interests None declared.

Patient consent for publication Not required.

Ethics approval This study design and protocol were approved by the ethics committee of Osaka University (approval number: 13 279-5).

Provenance and peer review Not commissioned; externally peer reviewed.

Data availability statement Data are available upon reasonable request. All data relevant to the study are included in the article or uploaded as supplementary information. There is no additional information.

Open access This is an open access article distributed in accordance with the Creative Commons Attribution Non Commercial (CC BY-NC 4.0) license, which permits others to distribute, remix, adapt, build upon this work non-commercially, and license their derivative works on different terms, provided the original work is properly cited, appropriate credit is given, any changes made indicated, and the use is non-commercial. See: http://creativecommons.org/licenses/by-nc/4.0/.

\section{ORCID iDs}

Yukari Fujita http://orcid.org/0000-0002-8847-5654

Kenji Fukui http://orcid.org/0000-0003-2468-7559

Junji Kozawa http://orcid.org/0000-0001-9665-8947

\section{REFERENCES}

1 Wakabayashi Y, Usui Y, Okunuki Y, et al. Correlation of vascular endothelial growth factor with chemokines in the vitreous in diabetic retinopathy. Retina 2010;30:339-44.

2 Azuma K, Kawamori R, Toyofuku Y, et al. Repetitive fluctuations in blood glucose enhance monocyte adhesion to the endothelium of rat thoracic aorta. Arterioscler Thromb Vasc Biol 2006;26:2275-80.

3 Hotamisligil GS, Shargill NS, Spiegelman BM. Adipose expression of tumor necrosis factor-alpha: direct role in obesity-linked insulin resistance. Science 1993;259:87-91. 
4 Hotamisligil GS. Inflammation and metabolic disorders. Nature 2006;444:860-7.

5 Manne V, Handa P, Kowdley KV. Pathophysiology of nonalcoholic fatty liver disease/nonalcoholic steatohepatitis. Clin Liver Dis 2018;22:23-37.

6 Ehses JA, Perren A, Eppler E, et al. Increased number of islet-associated macrophages in type 2 diabetes. Diabetes 2007;56:2356-70.

7 Lundberg M, Seiron P, Ingvast S, et al. Insulitis in human diabetes: a histological evaluation of donor pancreases. Diabetologia 2017;60:346-53.

8 Donath MY, Shoelson SE. Type 2 diabetes as an inflammatory disease. Nat Rev Immunol 2011;11:98-107.

9 Murakami R, Saisho Y, Watanabe Y, et al. Pancreas fat and $\beta$ cell mass in humans with and without diabetes: an analysis in the Japanese population. J Clin Endocrinol Metab 2017;102:3251-60.

10 Ishibashi C, Kozawa J, Hosakawa Y, et al. Pancreatic fat is related to the longitudinal decrease in the increment of $\mathrm{C}$-peptide in glucagon stimulation test in type 2 diabetes patients. J Diabetes Investig 2020;11:80-7.

11 Ishibashi C, Kozawa J, Fujita Y, et al. Glucose intolerance after pancreatectomy was associated with preoperative hemoglobin A1c, insulin resistance, and histological pancreatic fatty infiltration. Pancreas 2018;47:e48-50.

12 Lee Y, Lingvay I, Szczepaniak LS, et al. Pancreatic steatosis: harbinger of type 2 diabetes in obese rodents. Int $J$ Obes 2010;34:396-400.
13 Kim SY, Kim H, Cho JY, et al. Quantitative assessment of pancreatic fat by using unenhanced CT: pathologic correlation and clinical implications. Radiology 2014;271:104-12.

14 Gerst F, Wagner R, Kaiser G, et al. Metabolic crosstalk between fatty pancreas and fatty liver: effects on local inflammation and insulin secretion. Diabetologia 2017;60:2240-51.

15 Eguchi K, Manabe I, Oishi-Tanaka Y, et al. Saturated fatty acid and TLR signaling link $\beta$ cell dysfunction and islet inflammation. Cell Metab 2012;15:518-33.

16 Saisho Y, Butler AE, Meier JJ, et al. Pancreas volumes in humans from birth to age one hundred taking into account sex, obesity, and presence of type-2 diabetes. Clinical Anatomy 2007;20:933-42.

17 Lee JS, Kim SH, Jun DW, et al. Clinical implications of fatty pancreas: correlations between fatty pancreas and metabolic syndrome. World J Gastroenterol 2009;15:1869-75.

18 Böni-Schnetzler M, Boller S, Debray S, et al. Free fatty acids induce a proinflammatory response in islets via the abundantly expressed interleukin-1 receptor I. Endocrinology 2009;150:5218-29.

19 Martino L, Masini M, Bugliani M, et al. Mast cells infiltrate pancreatic islets in human type 1 diabetes. Diabetologia 2015;58:2554-62.

20 Fröhlich M, Imhof A, Berg G, et al. Association between C-reactive protein and features of the metabolic syndrome: a population-based study. Diabetes Care 2000;23:1835-9.

21 Yamamoto C, Miyoshi H, Ono K, et al. Ipragliflozin effectively reduced visceral fat in Japanese patients with type 2 diabetes under adequate diet therapy. Endocr J 2016;63:589-96. 